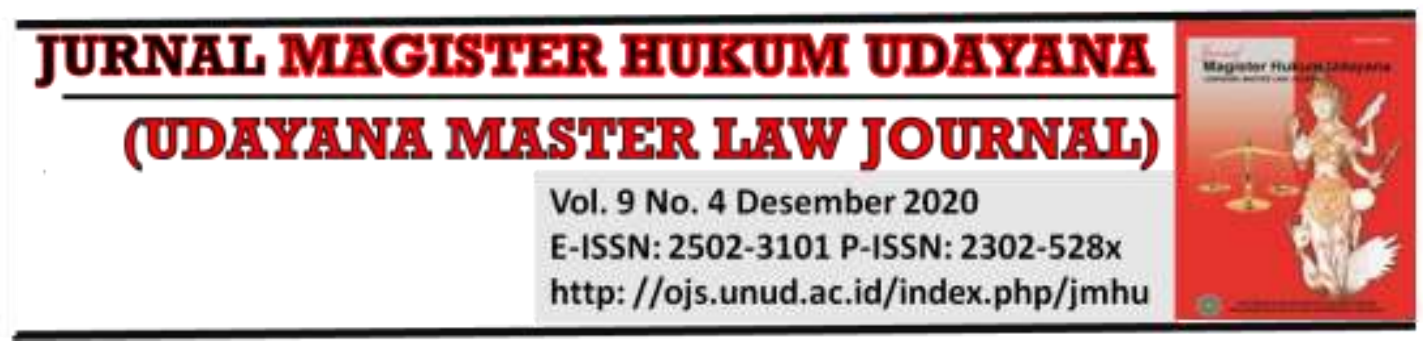

\title{
Pariwisata Kerta Masa: Gagasan Alternatif Kebijakan Pembangunan Pariwisata Bali
}

\section{Anak Agung Gede Duwira Hadi Santosa1, Luh Ayu Nadira Saraswati}

${ }^{1}$ Fakultas Hukum Universitas Udayana, E-mail: agung_santosa@unud.ac.id

${ }^{2}$ Fakultas Hukum Universitas Udayana, E-mail: luhayunadira@gmail.com

\begin{tabular}{l}
\hline Info Artikel \\
\hline Masuk: 19 Oktober 2020 \\
Diterima: 21 Desember 2020 \\
Terbit: 31 Desember 2020 \\
Keywords: \\
Kerta Masa; Policy; Tourism \\
Development \\
\\
Corresponding Author: \\
A.A Gede Duwira Hadi \\
Santosa, E-mail: \\
agung_santosa@unud.ac.id \\
Kerta Masa; Kebijakan; \\
Pembangunan Pariwisata \\
\end{tabular}

\begin{abstract}
Kerta Masa is a noble value that is passed down across generations and lives in Balinese society. Carrying the spirit of order, tranquility, togetherness, harmony, and prosperity, the concept of Kerta Masa can be applied more broadly as a basis for quality and sustainable tourism development policies in Bali Province, in which the tourism direction development policies currently tends to be quantity oriented. "The purpose of this study is to determine the tourism arrangements in Bali as stipulated in the Bali Provincial Regulation Number 10 year 2015 concerning the Bali Province Regional Tourism Development Master Plan for 2015-2029 and this research is expected to contribute to the evaluation of the Regional Regulation which elevates Kerta masa tourism as an alternative of tourism development policies in Bali. Normative legal research is a method used in writing this journal that analyzes tourism policies before and after the COVID-19 pandemic and raises Kerta Masa tourism as an alternative idea for Bali tourism development policies. The results showed that Bali tourism, which is currently quantity oriented, is very vulnerable so that "No Tourist High Risk" and in the future Kerta Masa Tourism are very potential in making Bali's tourism climate more qualified and other leading industries can grow optimally in realized "No Tourist Low Risk".
\end{abstract}

\begin{tabular}{l}
\hline Abstrak \\
\hline Kerta Masa merupakan nilai adiluhung yang diwariskan secara \\
turun temurun dan hidup dalam masyarakat Bali. Mengusung \\
semangat keteraturan, ketentraman, kebersamaan, keharmonisan, \\
dan kesejahteraan, konsep Kerta Masa dapat diaplikasikan lebih \\
luas lagi yakni sebagai landasan dalam kebijakan pembangunan \\
pariwisata yang berkualitas dan berkelanjutan di Provinsi Bali, \\
yang mana arah kebijakan Pembangunan Pariwisata saat ini \\
masih cenderung berorientasi kuantitas. Tujuan dari penelitian \\
ini adalah untuk mengetahui pengaturan pariwisata di Bali \\
dalam Peraturan Daerah Provinsi Bali Nomor 10 Tahun 2015 \\
Tentang Rencana Induk Pembangunan Kepariwisataan Daerah \\
Provinsi Bali Tahun 2015-2029 serta penelitian ini diharapkan \\
menjadi sumbang saran dalam evaluasi Peraturan Daerah \\
tersebut yang mengangkat pariwisata kertamasa sebagai gagasan \\
alternatif kebijakan pembangunan pariwisata Bali. Penelitian
\end{tabular}


hukum normatif adalah metode yang digunakan dalam penulisan jurnal ini yang menganalisis kebijakan pariwisata sebelum dan pasca pandemi COVID-19 serta mengangkat pariwisata kerta masa sebagai gagasan alternatif kebijakan pembangunan pariwisata Bali. Hasil penelitian menunjukkan bahwa pariwisata Bali yang saat ini beorientasi kuantitas sangat rentan sehingga "No Tourist High Risk" dan kedepannya Pariwisata Kerta Masa sangat potensial dalam menjadikan iklim pariwisata Bali lebih berkualitas dan industri unggulan lainnya dapat bertumbuh secara maksimal dalam mewujudkan "No Tourist Low Risk".

\section{Pendahuluan}

Pariwisata sudah lama dikenal sebagai tulang punggung perekonomian Bali, berbagai kebijakan strategis telah dirancang untuk menggenjot sektor ini yang tercermin dalam berbagai peraturan daerah dan sejumlah peraturan turunan lainnya. Pariwisata merupakan salah satu andalan dalam perolehan devisa bagi pembangunan baik nasional maupun daerah. Oleh sebab itu, pembangunan pariwisata Indonesia harus mampu menciptakan inovasi baru untuk mempertahankan dan meningkatkan daya saing secara berkelanjutan. ${ }^{1}$ Industri kepariwisataan berkembang sangat signifikan dan mempengaruhi iklim investasi baik secara regional di Bali, maupun secara nasional di seluruh Indonesia. Khususnya di Bali yang merupakan salah satu pulau tujuan pariwisata kelas dunia, dalam perspektif investasi keberadaannya bagaikan gula-gula yang selalu dikerubuti semut. Begitulah Bali yang selalu diincar oleh investor untuk menanamkan modalnya dalam rangka mendapatkan keuntungan yang sebanyak-

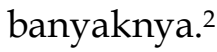

Cikal bakal industrialisasi pariwisata di Indonesia bisa dilihat dari hadirnya industriindustri pariwisata di daerah yang memiliki potensi akan keindahan alamnya. Loncatan besar terjadi ketika diberlakukan UU Agraria Tahun 1960 yang kemudian diikuti UU Penanaman Modal Asing Tahun 1967 sejak saat itu pemodal-pemodal asing berlomba-lomba menanamkan modalnya di Indonesia, ${ }^{3}$ termasuk berinvestasi disektor pariwisata. Seiring dengan perkembangan investasi di sektor paariwisata, di Bali berbagai kebijakan dan strategi yang diluncurkan pemerintah dalam bidang pariwisata yang cenderung berorientasi kuantitas. Peningkatan volume kunjungan dan berbagai fasilitas pariwisata diharapkan mampu menjadi mesin penopang kehidupan di Bali, sebagaimana disebutkan dalam Pasal 10 Peraturan Daerah Provinsi Bali Nomor

\footnotetext{
${ }^{1}$ Primantara, P.I. (2018). Perlindungan Hukum Terhadap Wisatawan dalam Pasokan Jasa Pariwisata oleh Biro Perjalanan Wisata. Jurnal Magister Ilmu Hukum, 4(2), 263-271. doi: https://doi.org/10.24843/JMHU.2015.v04.i02.p06, p. 264

2 Adnyana, I. N. B., Nahak, S. \& Widia, I. K. (2017). Kekuatan Mengikat MOU Antara PT. Bali Tourism Development Coporation (BTDC) Persero dengan PT. Jaya Makmur Bersama Dalam Perspektif Investasi Pada Sektor Industri Pariwisata. Jurnal Prasada 4(2), 12-23. doi: https://doi.org/10.22225/jhp.4.2.139.12-23, p.13

${ }^{3}$ Ahmad, R. \&Yunita, R. D. (2019). Ketidakadilan Gender Pada Perempuan Dalam Industri Pariwisata Taman Nasional Komodo Jurnal Sosiologi Pendidikan Humanis 4(2), 84-93. doi: http://dx.doi.org/10.17977/um021v4i2p84-93, p.85
} 
10 Tahun 2015 tentang Rencana Induk Pembangunan Kepariwisataan Daerah Provinsi Bali Tahun 2015-2029 (RIPPARDA Provinsi Bali).

Orientasi kebijakan pembangunan pariwisata bali yang cendrung kearah kuantitas unggulnya terkesan semakin meninggalkan nilai-nilai adiluhung yang telah lama hidup dan dianut masyarakat Bali.Tahun 2020 ini secara tidak terduga pandemi COVID-19 melumpuhkan kehidupan pariwisata di bali yang tentu saja berimbas ke berbagai sektor. Dalam situasi seperti ini, kita dihadapkan kepada kenyataan bahwa pariwisata merupakan sektor yang rentan dan tidak dapat dibiarkan berdiri sendiri sebagai sumber utama perekonomian Bali. Namun kesempatan ini juga merupakan peluang bagi Pemerintah Daerah Provinsi Bali untuk menyesuaikan kembali strategi yang telah diterapkan dalam sejumlah kebijakan pariwisata di Bali yang sesuai dengan nilai adiluhung yang telah lama hidup dan dianut masyarakat Bali yang salah satunya nilai-nilai Kerta Masa.

Konsep Kerta Masa, yang diyakini sebagai musim kemakmuran, masa kemajuan dam zaman keemasan, banyak nilai yang dapat digali dan diterapkan dalam kebijakan pembanguna pariwisata Bali. Menurut I Gusti Ketut Kaler Kerta Masa adalah peraturan tentang tata acara bercocok tanam padi menurut masa (musim) yang ditetapkan dan berlaku dalam suatu subak atau peraturan tentang musim bertanam padi yang kerta (tertib) yang ditetapkan dan berlaku dalam suatu subak, selanjutnya dikatakan I Gusti Ketut Kaler, untuk dapat menerapkan Kerta Masa maka beberapa syarat haruslah dipenuhi oleh subak bersama para anggotanya masing-masing yaitu: pertama mengenal perhitungan musim dan cuaca agar Kerta Masa dapat serasi dengan turunnya hujan, musim terang, bertiup angin dan sebagainya; kedua mengetahui besarnya debit air rata-rata dari sumber air milik subak baik pada musim kemarau maupun hujan sehingga dapat mengatur aliran air apakah memungkinkan untuk mengaliri air ke seluruh anggota subak secara serantak kalau tidak dimungkinkan secara serentak maka akan dilakukan secara bergilir; dan ketiga untuk para anggotanya haruslah mengetahui letak sawahnya di hulu atau di hilir aliran air, kalau di hulu maka akan dapat menerima aliran air yang masih sejuk dan dihilir airnya lebih hangat yang mengakibatkan padi tumbuh lebih cepat dihulu oleh sebab itu penanaman padi dilakukan oleh lebih awal oleh anggota subak yang sawahnya terletak dihilir agar terjadi keserentakan saat padi bunting/penyerbukan sehingga padi dapat dipanen secara bersama-sama.

Tradisi Kerta Masa ini dalam perkembangannya mengalami ancaman dimulai pada tahun 1970 an, sebagaimana disampaikan oleh Wayan Windia bahwa situasi pangan di Indonesia sangat rawan sehingga pemerintah memfokuskan pembangunan nasional di sektor pertanian, pada masa itu dibangunlah irigasi dengan sistem yang masif dan padi dengan varietas baru mulai diperkenalkan yang diberi nama PB-5 dan PB8 dengan memanfaatkan saprodi yang benar-benar anorganik dan usia padi jenis ini amat pendek 105 hari (setengah dari usia padi lokal era itu). Pemerintah juga memberikan beragam subsidi dan perlindungan kepada para petani yang memberikan petani peluang untuk menanam padi sampai dengan tiga kali dalam setahun, sesaat setelah panen padi maka sawah bisa dibajak lagi tanpa harus menuggu lebih lama, sehingga padi dapat ditanam kembali. Para Petani saling berlomba bercocok tanam padi hingga tiga kali dalam setahun sebagai implikasi dari orientasi kebijakan 
Pemerintah, sehingga kemudian munculah sitem tanam sebagai kebalikan dari Kerta Masa yang disebut Tulak Sumur.

Dari pemaparan di atas, terlihat bahwa kebijakan pembangunan pariwisata yang berorientasi kuantitas mengarah ke konsep Tulak Sumur, sementara kebijakan yang kita harapkan adalah menuju Pariwisata Kerta Masa. Tahun 2021 merupakan tahun evaluasi dari RIPPARDA Provinsi Bali. Dalam rangka mengakomodir perkembangan usaha kepariwisataan serta efektifitas pelaksanaan pembinaan, pengawasan, dan pengendalian terhadap usaha kepariwisataan di daerah dipandang perlu mengatur ketentuan Kepariwisataan. ${ }^{4}$ Dalam beberapa kewenangan yang di berikan kepada pemerintah daerah untuk pengelolaan tata ruang dengan mempertimbangkan atau memperhatikan aspek-aspek yang ada seperti lingkungan, kependudukan, kemampuan keuangan dan sumber daya manusianya itu sendiri sebagai potensi yang di milikinya. Pengelolaan tata ruang bukan saja sekedar membagi bagi wilayah ke dalam beberapa kawasan dengan alasan percepatan pembangunan dan untuk mendatangkan investor tanpa melihat aspek aspek hukum dan lingkungan yang dapat menimbulkan perubahan perubahan kelestariannya. ${ }^{5}$

Keberhasilan sektor pariwisata, jika dilihat dari kajian dampak, semestinya berdampak searah positif terhadap sektor pertanian yang merupakan pelestari alam dan budaya Bali sebagai produk utama pariwisata Bali. Semestinya, bertambahnya hotel dan restoran memerlukan logistik bahan baku untuk pariwisata Bali akan meningkat, namun peningkatan tersebut belum mampu diperankan oleh sektor pertanian Bali, kenyataannya justru kontradiksi terjadi padanya dengan semakin menyempitnya lahan produktif, dan minimnya minat generasi muda Bali terhadap sektor pertanian. ${ }^{6}$ Atas alasan itu peneliti sangat tertarik untuk melakukan penelitian mengenai Pariwisata Kerta Masa sebagai gagasan alternatif kebijakan pembangunan pariwisata Bali yang bertujuan untuk memahami dan mengetahui pengaturan pariwisata dalam mewujudkan pembangunan pariwisata yang berkualitas dan berkelanjutan serta penerapan konsep Kerta Masa dalam kebijakan pembangunan pariwisata di Bali. Permasalahan dalam penelitian ini diharapkan menjadi sumbang saran dalam evaluasi RIPPARDA Provinsi Bali.

Berdasarkan latar belakang masalah dalam penelitian ini, maka ada 2 (dua) rumusan masalah yang dapat dibahas dalam jurnal ini. Permasalahan pertama mengenai bagaimana pengaturan pariwisata di Bali dalam mewujudkan pembangunan pariwisata yang berkualitas dan berkelanjutan kemudian untuk permasalahan yang kedua adalah bagaimana penerapan konsep Kerta Masa dalam kebijakan pembangunan pariwisata di Bali.

\section{Metode Penelitian}

4 Pratama, A., Minin, D., \& Isnaini, Isnaini (2019). Tinjauan Yuridis Peranan Pemerintah Daerah Dalam Mewujudkan Pemerintahan Yang Baik Dalam Bidang Perizinan Pariwisata. ARBITER: Jurnal Ilmiah Magister Hukum, 1(1), 31-41. doi: https:// doi.org/10.31289/arbiter.v1i1.103, p. 34

${ }^{5}$ Saputra, L. A. D. N. (2020). Pelanggaran Pemanfaatan Tata Ruang Dalam Pembangunan Sarana Akomodasi Pariwisata di Gili Trawangan. Media Bina Ilmiah 14(10), 3027-3214. doi: https://doi.org/10.33758/mbi.v14i10.528, p.3207

${ }^{6}$ Utama, I. G. B. R. (2013). Strategi Menuju Pariwisata Bali yang Berkualitas. Jurnal Kajian Bali: Pariwisata Bali dan Warisan Budaya, 3(2), 69-90. doi: https://ojs.unud.ac.id/index.php/kajianbali/article/view/15675, p. 77 
Penelitian hukum normatif diterapkan dalam tulisan ini sebagai metode penelitian terhadap aspek hukum suatu permasalahan dengan cara menganalisis berbagai bahan hukum mulai dari yang primer sampai sekunder untuk selanjutnya ditautkan dengan isu hukum yang ada. ${ }^{7}$ Pendekatan perundang-undangan (statute approach) dipilih sebagai pendekatan yang diterapkan dalam penulisan jurnal ini. Statute approach diterapkan dengan mengkaji semua produk hukum mulai dari undang-undang hingga peraturan yang relevan dengan permasalahan hukum yang dibahas. Penelitian ini menitikberatkan pada argumentasi hukum yang dibangun dalam kajian peraturan hukum yang ada yakni Peraturan Daerah Provinsi Bali Nomor 10 Tahun 2015 Tentang Rencana Induk Pembangunan Kepariwisataan Daerah Provinsi Bali Tahun 2015-2029. Tehnik Studi dokumen diaplikasikan dalam jurnal ini sebagai teknik penelusuran bahan hukum dengan analisis kualitatif sebagai analisis kajian.

\section{Hasil dan Pembahasan}

\subsection{Pengaturan Pariwisata di Bali}

\subsubsection{Pengaturan Pembangunan Pariwisata dalam Peraturan Daerah Nomor 10 Tahun 2015}

Industri pariwisata yang memainkan peran sentral mulai terlihat ketika Perang Dunia II berakhir. Di era itu lonjakan pariwisata yang begitu masif muncul sebagai kekuatan baru dalam bidang ekonomi serta sosial. Sejatinya pariwisata beriringan dengan peradaban manusia, hal ini diindikasikan dengan adanya perjalanan agama dan perjalanan lainnya. Perjalanan jauh serta cara hidup yang berpindah-pindah juga merupakan gaya hidup yang mulai bertumbuh sejak masa prasejarah.

Berbicara mengenai kegiatan pariwisata, sesuatu yang umum terbayang adalah liburan, bepergian atau bersenang-senang di suatu lingkungan yang berbeda untuk menikmati hal baru. ${ }^{8}$ Sejarah peradaban barat dimulai dari abad 11 sampai 15, dalam kurun waktu tersebut ziarah ke tempat khusus dengan alasan relijius menjadi model baru dalam perkembangan pariwisata, selanjutnya era perjalanan manusia mengelilingi berbagai negara dan benua dengan berpindah-pindah tempat dimulai sejak abad 17 sampai 20 yang kemudian kebiasaan ini memunculkan budaya migrasi, dimana orang-orang berpindah untuk mendiami tempat baru seolah-olah merupakan daerah asli mereka sementara kalangan kelas atas di era itu hanya singgah sementara hanya untuk berlibur. Alasan orang melakukan perjalanan kemudian semakin berkembang, selain untuk berwisata mereka juga berpergian untuk melakukan perjalann religius, migrasi, keperluan studi, berdagang maupun perang.

Di tahun 1740 istilah Grand Tour muncul di Inggris Raya dan Eropa dan Leisure Tour atau Tourism merupakan cikal bakal dari era Barat dimana pasangan muda-mudi dari kalangan menengah atas melakukan perjalanan panjang dengan berbagai tujuan, entah itu menyenangkan diri, pendidikan tujuan lainnya. Thomas Cook pada tahun 1840 menginisiasi paket tur inklusif yang modern untuk perjalanan sekelompok orang.

\footnotetext{
${ }^{7}$ Hartono \& C.F.G. Sunaryati. (2006). Penelitian Hukum di Indonesia Pada Akhir Abad Ke-20. Bandung: Alumni, h.140.

8 Thama, A. P., \& Dharmawan, N. K. S. (2019). Penyelenggaraan Pariwisata Olahraga: Perspektif Rekomendasi Pemerintah Daerah. Akta Comitas: Jurnal Hukum Kenotariatan 4(2), 213-226. doi: https://doi.org/10.24843/AC.2019.v04.i02.p05, p.215
} 
Menurut Adam Smith istilah wisatawan yang semula memiliki citra negatif karena dianggap hanya melakukan sesuatu yang tidak penting akhirnya pada tahun 1770 turis memberikan pengaruh baru dengan dimulainya perjalanan yang menggunakan moda transportasi masal. Abad ke-20 khususnya tahun 1960-1980 merupakan puncak perkembangan dunia pariwisata dimana jumlah wisatawan meningkat pesat dari sejumlah survey yang diadakan di era itu.

Di Indonesia sendiri, tahun 1910 merupakan cikal bakal perkembangan pariwisata dengan didirikannya VTV (Vereeneging Toeristen Verkeer) sebagai tour operator dan travel agent yang dibentuk oleh Belanda di Batavia yang saat itu begitu giat mempromosikan Jawa dan Bali sebagai destinasi pariwisata di Indonesia. ${ }^{9}$ Selanjutnya disusul dengan berdiringan berbagai cabang tour operator dan travel agent lainnya seperti Lislind (Lissonne Lindeman) di tahun 1926 yang berubah nama menjadi Nitour (Nederlandsche Indische Touriten Bureau) di tahun 1928, Kemudian ada juga KPM yang merupakan anak perusahaan Belanda yang secara rutin melayani pelayaran dan menghubungan wisatawan ke berbagai rute seperti Bali, Batavia, Makassar dan Surabaya.

Dari Uraian singkat sejarah pengertian pengertian tujuan kepariwisataan yang diatur di dalam UU Pariwisata dapat diketetahui bahwa Pariwisata mengandung berbagai dimensi. Pariwisata tidak hanya menyangkut persoalan ekonomi namun juga isu sosial, politik, budaya dan lainnya. Pariwisata merupakan suatu sistem multi kompleks dengan mengaitkan berbagai aspek yang berpengaruh pada aspek lainnya dimana dalam beberapa kurun waktu terakhir pariwisata memegang peranan penting sebagai penggerak dinamika masyarakat yang berpengaruh pada perubahan sosial budaya.

Salah satu jenis pariwisata yang menggunakan sumberdaya budaya sebagai modal utama dalam atraksi wisata disebut pariwisata budaya. Pariwisata budaya memberikan kesempatan kepada wisatawan untuk melakukan kontak langsung dengan masyarakat lokal dan kepada individu yang memiliki pengetahuan khusus tentang sesuatu objek budaya. Jenis pariwisata ini memberikan variasi yang luas menyangkut budaya, mulai dari seni pertunjukkan, seni rupa, festival, makanan tradisional, sejarah, pengalaman nostalgia dan cara hidup yang lain. ${ }^{10}$

Pariwisata budaya merupakan salah satu sektor wisata yang banyak dikembangkan oleh pemerintah daerah akhir-akhir ini. Menurut Nafila (2013), bahwa pariwisata budaya adalah salah satu jenis pariwisata yang menjadikan budaya sebagai daya tarik utama. Dimana di dalam pariwisata budaya ini wisatawan akan diapndu untuk disamping mengenali sekaligus memahami budaya dan kearifan pada komunitas lokal tersebut. Disamping itu, pengunjung akan dimanjakan dengan pemandangan, tempattempat bersejarah sekaligus museum, representasi nilai dan sistem hidup masyarakat

\footnotetext{
9 Pitana, I G. \& Diarta, I K. S. (2009) Pengantar Ilmu Pariwisata. Yogyakarta: Andi Ofset, h. 32

${ }^{10}$ Rahmi, S.A. (2016). Pembangunan Pariwisata Dalam Perspektif Kearifan Lokal. Reformasi: Jurnal Ilmiah Ilmu Sosial dan Ilmu Politik, 6(1), 2407-6864. doi: http://dx.doi.org/10.33366/rfr.v6i1.679, p.78
} 
lokal, seni (baik seni pertunjukan atau pun seni lainnya), serta kuliner khas dari masyarakat asli atau masyarakat lokal yang bersangkutan. ${ }^{11}$

Pariwisata budaya juga mempunyai nilai profit ekonomi dan profit budaya yang saling melengkapi satu dengan yang lainnya. Potensi budaya daerah yang beragam di Indonesia menempatkan pariwisata budaya sebagai salah satu perintis utama dalam mencapai tujuan ekonomi Indonesia.Dengan menjadikan destinasi pariwisata budaya sebagai tujuan kunjungan para wisatawan khususnya wisatawan manca negara maka pariwisata budaya menjadi acuan yang nyata bagi Indonesia untuk mengimplementasikan diplomasi kebudayaan. ${ }^{12}$

Dalam praktiknya, kebudayaan masyarakat adat Bali dikelola dan diselenggarakan secara mandiri oleh masyarakatnya, namun keuntungan dari usaha jasa pariwisata cenderung hanya dinikmati oleh pemerintah dan pengusaha jasa pariwisata. Dari sekian banyak biaya yang dikeluarkan oleh masyarakat adat Bali untuk memelihara dan mempertahankan kebudayaannya, nampaknya tidak ada timbal balik yang setimpal baik dari pemerintah maupun pengusaha jasa pariwisata. ${ }^{13}$

Pariwisata selalu menjadi sektor yang terus dikembangkan pemerintah. DPR RI telah menetapkan UU No. 10 Tahun 2009 tentang Kepariwisataan yang menggantikan UU No. 9 Tahun 1990. Secara regulatif, undang-undang tersebut bertujuan untuk mendorong usaha kecil dan menengah agar dapat membantu terciptanya Sustainable Tourism Industry. Undang-undang sebelumnya dianggap tidak mampu untuk menjawab tantangan dan harapan ke depan bagi pariwisata Indonesia. Sektor pariwisata dapat dikatakan bersentuhan langsung dengan masyarakat dengan tingkat ekonomi yang paling bawah, karena mereka-mereka itu yang akan melakukan kontak langsung dengan para wisatawan asing. Untuk itulah UU No. 10 Tahun 2009 ini ditetapkan, sehingga para pengrajin, pemandu wisata, dan para pelaku wisata kecil dan menengah dapat dibina dan dikembangkan sesuai dengan aturan yang berlaku14 Wisata dalam undang-undang ini diartikan sebagai kegiatan perjalanan yang dilakukan oleh seseorang atau sekelompok orang dengan mengunjungi tempat tertentu untuk tujuan rekreasi, pengembangan pribadi, atau mempelajari keunikan daya Tarik wisata yang dikunjungi dalam jangka waktu sementara (Pasal 1 ayat (1) UU No. 10 Tahun 2009). ${ }^{15}$

11 Prasodjo, T. (2017). Pengembangan Pariwisata Budaya dalam Perspektif Pelayanan Publik. Jurnal Office 3(1), 7-12. doi: https:// doi.org/10.26858/jo.v3i1.3448, p.8

12 Prabhawati, A. (2018). Upaya Indonesia dalam Meningkatkan Kualitas Pariwisata Budaya Melalui Diplomasi Kebudayaan. Journal of Tourism and Creativity, 6(1), 2407-6864. doi: http://dx.doi.org/10.33366/rfr.v6i1.679, p.78

${ }^{13}$ Salain, M. S. P. D., (2017). Perlindungan Hukum Terhadap Kebudayaan Bali Sebagai Sumber Daya Ekonomi Pariwisata. Kertha Patrika, 39(1), 1-15. doi: https://doi.org/10.24843/KP.2017.v39.i01.p01, p.2

14 Yuli,A. (2011). City Branding Sebagai Strategi Pengembangan Pariwisata Ditinjau Dari Aspek Hukum Merek (Studi Kasus City Branding Daerah Istimewa Yogyakarta Sebagai Daerah Tujuan Wisata Unggulan di Indonesia). Qistie Jurnal Ilmu Hukum,5(1), 50-68. doi: dx.doi.org/10.31942/jqi.v5i1.600, p. 51

${ }^{15}$ Sarsiti, Sarsiti, \& Taufiq, M. (2013). Penerapan Perlindungan Hukum Terhadap Wisatawan yang Mengalami Kerugian di Obyek Wisata (Studi di Kabupaten Purbalingga). Jurnal Dinamika Hukum,12(1), 2407-6562. doi: 10.20884/1.jdh.2012.12.1.198, p. 27 
Dalam Undang-Undang Kepariwisataan disebutkan bahwa yang mendasari pembangunan pariwisata adalah asas-asas berikut: manfaat, kekeluargaan, adil dan merata, keseimbangan, kemandirian, kelestarian, demokratis, kesetaraan, partisipatif, berkelanjutan,dan kesatuan. Hal ini diaplikasikan dengan memperhatikan keunikan, kekhasan budaya, keanekaragaman, dan alam, serta kebutuhan manusia untuk berwisata dalam pelaksanaan rencana pembangunan kepariwisataan. Sejalan dengan amanat Undang-Undang Kepariwisataan, Pemerintah Daerah Provinsi Bali juga menerbitkan Peraturan Daerah Provinsi Bali Nomor 2 Tahun 2012 tentang Kepariwisataan Budaya Bali kemudian dikuatkan lagi dengan tebitnya Peraturan Daerah Provinsi Bali Nomor 10 Tahun 2015 Tentang Rencana Induk Pembangunan Kepariwisataan Daerah Provinsi Bali Tahun 2015-2029 sebagai pedoman kebijakan pariwisata Bali.

Arah kepariwisataan Bali dalam perkembangannya diatur dalam RIPPARDA Provinsi Bali meliputi: pembangunan destinasi pariwisata daerah, pembangunan pemasaran pariwisata daerah, dan pembangunan kelembagaan pariwisata daerah. Pasal-pasal dalam Peraturan Daerah ini memuat berbagai kebijakan dan strategi untuk mendukung visi pembangunan kepariwisataan daerah Bali yaitu mewujudkan pariwisata budaya yang berkelanjutan dan berkualitas serta memiliki daya saing yang berlandaskan Tri Hita Karana yang mampu mendorong pembangunan daerah dan kesejahteraan rakyat.

Dalam kurun tiga dekade terakhir Pariwisata merupakan penopang utama perekonomian Bali. Pernyataan itu tidaklah berlebihan apabila melihat data data mengenai kaitan antara Pariwisata dengan perekonomian Bali. Data Badan Pusat Statistik (BPS) 2018 menunjukan dalam 5 tahun terakhir Pariwisata memberikan kontribusi yang singnifikan bagi perekonomian Bali melalui penyedian akomodasi makanan dan minuman menyumbang Produk Domestik Regional Bruto (PDRB) tertinggi. Begitu pula data BPS 2019 menunjukan bahwa Pariwisata memberikan kontribusi dalam penyerapan tenaga kerja sehingga pada tahun 2019 pengangguran di Bali dibandingkan dengan daerah lain di Indonesia berada di posisi yang paling rendah. ${ }^{16}$ Peningkatan kunjungan wisatawan ke Bali dipengaruhi oleh hari libur nasional maupun hari raya keagamaan seperti Paskah, Nyepi, Galungan dan Kuningan, hal ini juga ikut turut mendorong peningkatan kinerja ekspor jasa. Beberapa kegiatan Meeting, Incentive, Convention dan Exhibition (MICE) khususnya yang dilakukan oleh korporasi asing, juga mendorong peningkatan ekspor jasa.

Di sisi lain banyak program pemerintah dalam pengembangan pariwisata kurang matang dipertimbangkan, khususnya mengenai keuntungan yang akan diperoleh apakah lebih besar daripada perusakan yang ditimbulkannya. Dalam hal ini

\footnotetext{
16 Sudapet, I. N., Sukoco, A., \& Setiawan, I. (2017). Model Integrasi Ekonomi Maritim Dan Pariwisata Di Daerah Guna Peningkatan Ekonomi Indonesia Timur. Jurnal Darussalam; Jurnal Pendidikan, Komunikasi dan Pemikiran Hukum Islam,9(1), 148-160. doi: https://doi.org/10.24843/KP.2017.v39.i01.p01, p.150
} 
pemerintah cenderung membangun kepariwisataan menjadi sesuatu yang mudah untuk dapat menghasilkan devisa yang sifatnya quick yielding. ${ }^{17}$

Kejadian tidak terduga terjadi di akhir tahun 2019 ketika Corona Virus Disease/COVID-19 mulai merebak kasusnya di wuhan china ketika akhir tahun 2019 yang kemudian meluas ke hampir seluruh negara di dunia. World Health Organization pada tanggal 11 maret 2020 menetapkan COVID-19 sebagai pandemi. Untuk penanggulangan dan penanganan COVID-19 negara-negara mengeluarkan berbagai kebijakan seperti lockdown, penutupan tempat hiburan, sekolah, tempat ibadah penutupan / pengetatan transportasi serta pintu masuk dan keluar negara.

Penanganan dan penanggulangan COVID-19 juga dilakukan oleh Pemerintah Indonesia. Setelah Presiden Jokowi menggumumkan kasus COVID-19 pertama di tanggal 2 Maret 2020 dengan 2 orang pertama yang dinyatakan terinfeksi, kemudian disusul konfirmasi kasus lainnya di Indonesia yang terus bertambah dan tersebar hampir diseluruh wilayah provinsi. Dalam rangka penanggulangan dan penanganan pandemi COVID-19 pemerintah membentuk Satuan Gugus Tugas Covid-19 ditingkat nasional sampai daerah-daerah. Pemerintah mengeluarkan berbagai kebijakan yang dituangkan kedalam peraturan perundang undangan; antara lain Keputusan Presiden Nomor 11 Tahun 2020 tentang Penetapan Darurat Kesehatan, Keputusan Presiden Nomor 12 Tahun 2020 tentang Penetapan Bencana Nasional, Peraturan Pemerintah Nomor 21 Tahun 2020 Tentang Pembatasan Sosial Bersekala Besar/ PSBB hingga kebijakan terakhir yang baru saja dikeluarkan oleh pemerintah bali pada 17 September 2020 yakni surat edaran Nomor 487/GugusCovid19/IX/2020 tentang Penguatan Pencegahan dan Pengendalian COVID-19 di Bali.

Sejak Maret sampai dengan Juli 2020, wabah pandemi Covid-19 diduga masih berdampak terhadap kunjungan turis ke Bali, pada bulan Juli 2020 tercatat hanya 47 kunjungan. Turis yang berkunjung ke Bali pada bulan Juli 2020 lebih besar datang melalui pelabuhan laut, yaitu sebanyak 31 kunjungan Wisatawan mancanegara (wisman) yang datang langsung ke Provinsi Bali pada Juli 2020 tercatat sebanyak 47 kunjungan. ${ }^{19}$

Berbagai kebijakan diambil negara- negara dalam rangka penanganan pandemi yang tengah dihadapi. Kebijakan-kebijakan seperti Karantina Wilayah (lock down), Pembatasan Sosisal Berskala Besar (PSBB) termasuk penutupan dan larangan beroperasinya fasilitas umum tempat hiburan atau wisata, penutupan atau pengetatan operasi berbagai moda transportasi termasuk terhadap pintu masuk dan keluar wilayah, secara otomatis memukul sektor Pariwisata tidak terkecuali Pariwisata Bali.

17 Arliman S., Laurensius (2018). Peran Investasi Dalam Kebijakan Pembangunan Ekonomi Bidang Pariwisata di Provinsi Sumatera Barat. Kanun Jurnal Ilmu Hukum, 20(2), 273-294. doi: https://doi.org/10.24815/kanun.v20i1.9828, p. 277

18 WHO Resmi Sebut Virus Corona Covid-19 sebagai Pandemi Global. (2020). Kompas.com. Retrieved from https://www.kompas.com/sains/read/2020/03/12/083129823/who-resmisebut-virus-corona-covid-19-sebagai-pandemi-global?page=all/, diakses 18 Desember 2020.

${ }^{19}$ Badan Pusat Statistik Provinsi Bali, (2020). Perkembangan Pariwisata Provinsi Bali Juli 2020. Retrieved from https://bali.bps.go.id/pressrelease/2020/09/01/717332/perkembanganpariwisata-provinsi-bali-juli-2020.html diakses 2 September 2020. 
Pandemi COVID-19 mengakibatkan turunnya kunjungan wisatawan ke Bali kecuali mereka yang masih tinggal di Bali karena pembatasan atau larangan operasi moda transportasi. Perusahaan yang bergerak disektor pariwisata tutup dan tidak memperoleh pendapatan akibatnya merumahkan karyawan dan menciptakan penganguran. Begitu pula dengan berbagai usaha yang terkait Pariwisata tidak beroperasi lagi, kalaupun masih beroperasi omzet penjualan turun drastis. Sementara itu Pemerintah Daerah kehilangan/penurunan Pendapatan Asli Daerah dari sektor Pariwisata sebagai konsekuensinya dapat mengancam pembiayaan penyelenggaraan pemerintahan. Secara umum menurut Wakil Gubernur Bali Dr. Ir. Tjokorda Oka Artha Ardana Sukawati, M.Si. atau yang biasa disebut Cok Ace menyebutkan bahwa kerugian yang diakibatkan pandemi terhadap Pariwisata Bali mencapai Rp, 9,7 Triliun setiap bulannya yang tentu saja hal ini memberikan efek domino terhadap sektor lainnya di Bali. ${ }^{20}$

\subsubsection{Evaluasi Kebijakan Pariwisata Bali Pasca Pandemi COVID-19}

Berdasarkan data yang berhasil dihimpun BPS, perekonomian di Bali yang diukur dengan PDRB pada triwulan II tahun 2020 tercatat tumbuh negatif sedalam -10,98\%, dan hal ini telah terjadi dalam dua periode triwulan berturut-turut. Berbagai pembatasan yang diberlakukan oleh pemerintah dalam upaya pengendalian penularan wabah hingga bulan Juni 2020, di antaranya dalam bentuk pemberhentian penerbangan komersial di Bandara Ngurah Rai, pengetatan protokol lalu lintas transportasi laut dan ASDP termasuk penyeberangan penumpang dalam rangka mudik lebaran, serta pembatasan kegiatan masyarakat, nampaknya berpengaruh langsung pada pencapaian nilai tambah sektor pariwisata. Pengaruh tersebut tercermin dari menurunnya data penyeberangan kendaraan pada jalur ASDP dan jalur angkutan udara, jumlah keberangkatan penumpang internasional di Bandara Ngurah Rai tercatat turun sedalam $-99,31 \%$, begitu juga dengan keberangkatan penumpang domestik turun sedalam $-94,49 \% .{ }^{21}$

Penurunan Penyediaan Akomodasi dan Makan Minum pada triwulan II-2020 kiranya berkaitan erat dengan penurunan aktivitas pariwisata di Bali selama pandemi COVID19. Kondisi ini tercermin dari kunjungan wisatawan mancanegara (wisman) yang pada triwulan II2020 terpuruk dengan penurunan -99,96\%. Pemberhentian penerbangan komersial di Bandara Ngurah Rai selama hampir sepanjang periode triwulan II-2020 (April, Mei dan Juni) kiranya juga tidak bisa dikesampingkan pengaruhnya. Lebih lanjut, keterpurukan ini dapat dilihat dari rata-rata TPK (Tingkat Penghunian Kamar/Occupancy Rate) hotel berbintang yang pada pada triwulan II-2020 tercatat hanya bersisa tinggal sekitar 2,45\%.22 Selain penyediaan akomodasi, perlindungan sangat diperlukan untuk wisatawan di setiap destinasi pariwisata. Mengingat kegiatan pariwisata berintikan pengamanan terhadap keselamatan wisatawan, kelestarian dan

20 Dampak Pandemi Covid-19, Pariwisata Bali Rugi Rp 9,7 Triliun Tiap Bulan (2020). Kompas.com. Retrieved from https://regional.kompas.com/read/2020/05/13/17591091 /dampak-pandemi-covid-19-pariwisata-bali-rugi-rp-97-triliun-tiap-bulan., diakses 18 Desember 2020

${ }^{21}$ Badan Pusat Statistik Provinsi Bali, (2020). Pertumbuhan Ekonomi Bali Semster I - 2020. Retrieved from https://bali.bps.go.id/pressrelease/2020/08/05/717412/pertumbuhanekonomi-bali-semester-i-----2020.html diakses 2 September 2020.

22 Ibid. 
mutu lingkungan, atau ketertiban dan ketentraman masyarakat, yang diselenggarakan berdasarkan ketentuan perundang-undangan yang berlaku. ${ }^{23}$

Arah kebijakan Pariwisata Bali dapat dilihat dalam Peraturan Daerah Nomor 10 Tahun 2015 tentang Rencana Induk Pembangunan Kepariwisataan Daerah Provinsi Bali Tahun 2015 sampai dengan 2029. Dalam Pasal 9 huruf (c) tujuan pembangunan kepariwisataan diharapkan dapat mewujudkan industri pariwisata yang mampu menggerakkan perekonomian daerah. Kemudian di pasal berikutnya disebutkan bahwa yang menjadi tujuan pengembangan kepariwisataan meliputi peningkatan jumlah kunjungan wisatawan nusantara dan mancanegara, peningkatan lama peningkatan jumlah pengeluaran wisatawan.

Kemudian dalam Pasal 46 huruf (e) disebutkan dengan jelas bahwa arah kebijakan pengembangan promosi pariwisata diwujudkan dalam bentuk pengembangan kegiatan promosi pariwisata, dan salah satu strateginya yakni: melaksanakan kolaborasi dengan berbagai maskapai penerbangan untuk mempromosikan program wisata dengan harga menarik untuk tiket pesawat bagi wisatawan pada saat tingkan kunjungan wisatawan rendah (low season). Pasal tersebut menekankan bahwa strategi promosi pariwisata di Bali cenderung mengarah ke pariwisata berbasis kuantitas, yang mana pariwisata sebagai sektor utama diharapkan mampu memberikan performa maksimal di setiap tahunnya.

Ketentuan pasal 46 mengenai arah strategi pengembangan promosi menunjukan arah kebijakan Pariwsata Bali lebih berorientasi pada kuantitas daripada kualitas, tidak mengenal musim karena setiap saat adalah musim wisata sehingga Bali harus menyesuaikan diri dengan keinginan wisatawan bukan wisatawan yang menyesuaikan diri dengan sumber Kepariwisataan Bali. Meminjam istilah dalam subak arah kebijakan pariwisata yang demikian analogi dengan Tulak Sumur yang merupakan kebalikan dari Kerta Masa. Secara umum seperti inilah potret Pariwisata Bali sebelum Pandemi Covid-19.

Pasca pandemi COVID -19 Pariwisata Bali mengalami kerugian perekonomian yang besar. Dampak COVID-19 terhadap perekonomian Bali membuktikan bahwa adanya risiko yang tinggi apabila hanya menempatkan Pariwisata sebagai penopang utama perekonomian Bali istilahnya "No Tourist High Risk". Untuk itu dilihat dari sisi positifnya Pandemi COVID-19 ini dapat dijadikan momentum untuk mengevaluasi kebijakan Pariwisata Bali sebagaimana diatur dalam Perda No 10 Tahun 2015. Sehingga ke depan arah pembangunan kepariwisataan dapat beriringan dengan nilainilai pariwisata kerta masa untuk pemerataan pembangunan di berbagai sektor dan "No Tourist Low Risk" dapat diwujudkan.

\subsection{Pariwisata Kerta Masa sebagai gagasan alternatif kebijakan pembangunan pariwisata Bali}

Pasca pandemi COVID-19 banyak pihak yang resah akan keberlangsungan sektor pariwisata kedepannya. Dengan berbagai strategi dan upaya yang dilakukan oleh

\footnotetext{
${ }^{23}$ Oktaviarni, F. (2018). Perlindungan Hukum Terhadap Wisatawan Menurut Undang-Undang Nomor 10 Tahun 2009 Tentang Kepariwisataan. Wajah Hukum 2(2), 138-145. doi: http://dx.doi.org/10.33087/wjh.v2i2.34, p.139
} 
pemerintah, sepanjang kebijakan pariwisata Bali masih berorientasi kuantitas justru akan menempatkan Bali dalam posisi yang sangat riskan. Apabila dikaji dari sisi teori welfare state Pemerintah Daerah sebagai pengampu kebijakan di Bali perlu mencari alternatif kebijakan pariwisata untuk keberlangsungan pariwisata di Bali dan kesejahteraan masyarakatnya. Welfare State bisa dilihat dari sudut pandang terbatas dan sudut pandang luas. Dari perspektif terbatas, welfare state merupakan tata kelola keuangan pemerintah yang ditujukan untuk sektor rumah tangga (konsumsi dalam negeri, penghasilan, asuransi), serta subsidi atau dana sosial untuk kesehatan anak, pendidikan, kesehatan umum, dan perawatan orang tua. Dari sudut pandang yang luas, welfare state bisa digambarkan sebagai intervensi pemerintah melalui kebijakan publik, termasuk diantaranya kebijakan perumahan, peraturan tenaga kerja, undangundang perpajakan, serta kebijakan lingkungan, dengan tujuan untuk kesejahteraan masyarakat. ${ }^{24}$

Lebih lanjut dalam teori sistem hukum, Friedman menyatakan ada tiga unsur pembentuk sistem hukum yakni substansi hukum (legal substance), struktur hukum (legal structure) dan budaya hukum (legal culture). Struktur hukum adalah komponen struktural atau organ yang bergerak di dalam suatu mekanisme, baik dalam membuat peraturan, maupun dalam menerapkan atau melaksanakan peraturan. Substansi hukum adalah produk dari struktur hukum, baik peraturan yang dibuat melalui mekanisme struktur formal atau peraturan yang lahir dari kebiasaan. Sedangkan budaya hukum adalah nilai, pemikiran, serta harapan atas kaidah Penguatan budaya hukum atau norma dalam kehidupan sosial masyarakat. ${ }^{25}$

Disisi lain dalam Pasal 237 Ayat 1 Undang-Undang Nomor 23 Tahun 2014 tentang Pemerintahan Daerah, secara tegas disebutkan bahwa asas pembentukan dan materi muatan Perda berpedoman pada ketentuan peraturan perundang-undangan dan asas hukum yang tumbuh dan berkembang dalam masyarakat sepanjang tidak bertentangan dengan prinsip Nekara Kesatuan Republik Indonesia. Beranjak dari teori dan peraturan yang telah dikemukakan diatas sudah sepatutnya Kerta Masa sebagai nilai yang telah lama hidup dalam masyarakat bali dapat diimplementasikan sebagai gagasan alternatif kebijakan pembangunan pariwisata di Bali. Dengan mengusung nilai-nilai adiluhung, seperti ketertiban, ketentraman, kebersamaan, keharmonisan dan kesejahteraan, Pariwisata Kerta Masa diproyeksikan sebagai solusi untuk menghindarkan Bali dari potensi resiko akibat pariwisata tulak sumur yang berorientasi kuantitas.

Pariwisata Kerta Masa juga dapat menjadi konsep pembangunan pariwisata berkelanjutan yang diselenggarakan dengan bertanggung jawab untuk memenuhi keperluan dan ide manusia di era ini, tanpa mengesampingkan potensi pemenuhan keperluan dan ide manusia dimasa yang akan datang. Oleh karena itu perencanaan

\footnotetext{
${ }^{24}$ Elviandri, E. (2019). Quo Vadis Negara Kesejahteraan: Meneguhkan Ideologi Welfare State Negara Hukum Kesejahteraan Indonesia. Mimbar Hukum, 31(2), 252-266. doi: https://doi.org/10.22146/jmh.32986, p. 254

25 Purba, I.P. (2017 Penguatan Budaya Hukum Masyarakat Untuk Menghasilkan Kewarganegaraan Transformatif. Jurnal Civic, 14(2), 146-153. doi: https://doi.org/10.21831/civics.v14i2.16050, p. 146
} 
pariwisata sangat penting dilakukan untuk terwujudnya bentuk pariwisata yang berkelanjutan.

Dalam konteks ini, model perencanaan pembangunan pariwisata yang berkelanjutan sangat dibutuhkan. Apalagi tingkat persaingan produk dan jasa di pasar pariwisata sudah semakin meningkat dengan derajat kualitas, teknologi, dan inovasi yang semakin tinggi, maka sebuah perencanaan pariwisata yang berkelanjutan mutlak diperlukan. Dalam perencanaan pembangunan pariwisata berkelanjutan harus memenuhi kriteria tertentu seperti menghormati budaya dan lingkungan masyarakat setempat, ekonomi dan cara hidupnya, perilaku adat dan kepemimpinannya, dmelibatkan penduduknya dalam proses perencanaan, pelaksanaan, pemeliharaan dan tanggung jawab keberlanjutan. Secara teoritis sebuah perencanaan yang baik akan menghasilkan suatu strategi dan kemampuan menghormati sumber daya pariwisata seperti itu secara berkelanjutan. ${ }^{26}$

Pariwisata Kerta Masa nantinya akan mengembalikan situasi pariwisata yang kondusif karena pariwisata tidak ditempatkan sebagai sumber pendapatan utama Bali, melainkan sebagai pendapatan sekunder sehingga sektor pariwisata dapat bertumbuh dan berkreasi sebagaimana mestinya tanpa adanya tuntutan industrialisasi. Karena pariwisata pun memiliki masanya tersendiri, ada kalanya dalam periode tertentu Bali akan ramai wisatawan dan di waktu lainnya akan sepi pengunjung. Dalam masa-masa sepi itulah diharapkan ada sektor-sektor lain yang akan mengisi dan menopang perekonomian Bali agar tetap eksis. Sektor-sektor potensial yang telah lama terpinggirkan seperti pertanian termasuk perternakan dan perikanan dapat ditata kembali sehingga mampu bangkit kembali dan menjadi sumber pendapatan primer. Bali sebelum dikenal menjadi destinasi wisata, mayoritas penduduknya merupakan masyarakat agraris yang telah memiliki konsep-konsep kuat dalam pelaksanaan pertanian salah satunya pengaturan pengairan atau irigasi yang disebut subak. Tidak berlebihan kiranya, apabila pasca pandemi ini sektor pertanian dapat diangkat kembali untuk tampil sebagai pionir perekonomian Bali, mengingat setelah sektor pariwisata terpukul, sektor pertanian ternyata menunjukkan pertumbuhan positif.

Kedepan Wisatawan yang akan mengikuti alur pariwisata Bali, bukan pariwisata Bali yang mengikuti kemauan wisatawan. Para petani mendapatkan pemasukan utama dari pertanian sementara mereka juga bisa mendapatkan pemasukan tambahan dari pariwisata sehingga tidak ada mutasi profesi besar-besaran. Sejatinya lahan pertanian maupun cara bercocok tanam juga merupakan daya tarik wisata. Di sisi lain kegiatan pariwisata juga tidak harus dilakukan setiap saat, namun disesuaikan dengan musim liburan yang mengikuti jadwal pola pertanian sehingga kedepan, diharapkan iklim pariwisata akan semakin kondusif.

\section{Kesimpulan}

Peraturan Daerah Provinsi Bali Nomor 10 Tahun 2015 Tentang Rencana Induk Pembangunan Kepariwisataan Daerah Provinsi Bali Tahun 2015-2029 sebagai pedoman kebijakan pembangunan kepariwisataan Bali cenderung mengarah ke

${ }^{26}$ Arid, I N. S. \& Rohman (2019). Perencanaan Pariwisata dan Keberlanjutan Lingkungan. Jakarta: Cakra Media Utama, h. 16 
pariwisata berbasis kuantitas. Sementara dengan adanya pandemi COVID -19 semakin mempertegas bahwa industri Pariwisata sangat rentan apabila dijadikan penopang utama perekonomian Bali dimana "No Tourist High Risk". Dengan menerapkan konsep Pariwisata Kerta Masa dalam kebijakan pembangunan pariwisata Bali nantinya diharapkan akan membangun situasi pariwisata yang kondusif karena pariwisata tidak ditempatkan sebagai sumber pendapatan utama Bali, melainkan sebagai pendapatan sekunder sehingga sektor pariwisata dapat bertumbuh dan berkreasi sebagaimana mestinya tanpa adanya tuntutan industrialisasi. Selanjutnya para wisatawan yang akan mengikuti alur pariwisata Bali, bukan pariwisata Bali yang mengikuti kemauan wisatawan, sehingga pemerataan pembangunan di sektor potensial lainnya semakin fokus dan terwujudnya "No Tourist Low Risk".

\section{Daftar Pustaka}

Buku

Arid, I N. S. \& Rohman (2019). Perencanaan Pariwisata dan Keberlanjutan Lingkungan. Jakarta: Cakra Media Utama, h. 16

Hartono \& C.F.G. Sunaryati. (2006). Penelitian Hukum di Indonesia Pada Akhir Abad Ke20. Bandung: Alumni.

Pitana, I G. \& Diarta, I K. S. (2009) Pengantar Ilmu Pariwisata. Yogyakarta: Andi Ofset.

\section{Jurnal:}

Adnyana, I. N. B., Nahak, S. \& Widia, I. K. (2017). Kekuatan Mengikat MOU Antara PT. Bali Tourism Development Coporation (BTDC) Persero dengan PT. Jaya Makmur Bersama Dalam Perspektif Investasi Pada Sektor Industri Pariwisata. Jurnal Prasada 4(2), 12-23.

Ahmad, R. \&Yunita, R. D. (2019). Ketidakadilan Gender Pada Perempuan Dalam Industri Pariwisata Taman Nasional Komodo Jurnal Sosiologi Pendidikan Humanis 4(2), 84-93.

Arliman S., L. (2018). Peran Investasi Dalam Kebijakan Pembangunan Ekonomi Bidang Pariwisata di Provinsi Sumatera Barat. Kanun Jurnal Ilmu Hukum, 20(2), 273-294.

Elviandri, E. (2019). Quo Vadis Negara Kesejahteraan: Meneguhkan Ideologi Welfare State Negara Hukum Kesejahteraan Indonesia. Mimbar Hukum, 31(2), 252-266.

Oktaviarni, F. (2018). Perlindungan Hukum Terhadap Wisatawan Menurut UndangUndang Nomor 10 Tahun 2009 Tentang Kepariwisataan. Wajah Hukum 2(2), 138-145.

Prabhawati, A. (2018). Upaya Indonesia dalam Meningkatkan Kualitas Pariwisata Budaya Melalui Diplomasi Kebudayaan. Journal of Tourism and Creativity, 6(1), 2407-6864.

Prasodjo, T. (2017). Pengembangan Pariwisata Budaya dalam Perspektif Pelayanan Publik. Jurnal Office 3(1), 7-12.

Pratama, A., Minin, D., \& Isnaini, Isnaini (2019). Tinjauan Yuridis Peranan Pemerintah Daerah Dalam Mewujudkan Pemerintahan Yang Baik Dalam Bidang Perizinan Pariwisata. ARBITER: Jurnal Ilmiah Magister Hukum, 1(1), 31-41.

Primantara, P.I. (2018). Perlindungan Hukum Terhadap Wisatawan dalam Pasokan Jasa Pariwisata oleh Biro Perjalanan Wisata. Jurnal Magister Ilmu Hukum, 4(2), 263-271.

Purba, I.P. (2017 Penguatan Budaya Hukum Masyarakat Untuk Menghasilkan Kewarganegaraan Transformatif. Jurnal Civic, 14(2), 146-153. 
Rahmi, S.A. (2016). Pembangunan Pariwisata Dalam Perspektif Kearifan Lokal. Reformasi: Jurnal Ilmiah Ilmu Sosial dan ilmu Politik, 6(1), 2407-6864.

Salain, M. S. P. D., (2017). Perlindungan Hukum Terhadap Kebudayaan Bali Sebagai Sumber Daya Ekonomi Pariwisata. Kertha Patrika, 39(1), 1-15.

Saputra, L. A. D. N. (2020). Pelanggaran Pemanfaatan Tata Ruang Dalam Pembangunan Sarana Akomodasi Pariwisata di Gili Trawangan. Media Bina Ilmiah 14(10), 3027-3214.

Sarsiti, Sarsiti, \& Taufiq, M. (2013). Penerapan Perlindungan Hukum Terhadap Wisatawan yang Mengalami Kerugian di Obyek Wisata (Studi di Kabupaten Purbalingga). Jurnal Dinamika Hukum,12(1), 2407-6562.

Sudapet, I. N., Sukoco, A., \& Setiawan, I. (2017). Model Integrasi Ekonomi Maritim Dan Pariwisata Di Daerah Guna Peningkatan Ekonomi Indonesia Timur. Jurnal Darussalam; Jurnal Pendidikan, Komunikasi dan Pemikiran Hukum Islam,9(1), 148160.

Thama, A. P., \& Dharmawan, N. K. S. (2019). Penyelenggaraan Pariwisata Olahraga: Perspektif Rekomendasi Pemerintah Daerah. Akta Comitas: Jurnal Hukum Kenotariatan 4(2), 213-226.

Utama, I. G. B. R. (2013). Strategi Menuju Pariwisata Bali yang Berkualitas. Jurnal Kajian Bali: Pariwisata Bali dan Warisan Budaya, 3(2), 69-90.

Yuli, A. (2011). City Branding Sebagai Strategi Pengembangan Pariwisata Ditinjau Dari Aspek Hukum Merek (Studi Kasus City Branding Daerah Istimewa Yogyakarta Sebagai Daerah Tujuan Wisata Unggulan Di Indonesia). Qistie Jurnal Ilmu Hukum,5(1), 50-668.

\section{Internet}

Dampak Pandemi Covid-19, Pariwisata Bali Rugi Rp 9,7 Triliun Tiap Bulan (2020). Kompas.com. Retrieved from https://regional.kompas.com/read/2020 /05/13/17591091 /dampak-pandemi-covid-19-pariwisata-bali-rugi-rp-97triliun-tiap-bulan., diakses 18 Desember 2020

WHO Resmi Sebut Virus Corona Covid-19 sebagai Pandemi Global. (2020).Kompas.com. Retrieved from https://www.kompas.com/sains/read /2020/03/12/083129823/who-resmi-sebut-virus-corona-covid-19-sebagaipandemi-global?page=all/, diakses 18 Desember 2020

\section{Peraturan Perundang-undangan}

Undang-Undang Republik Indonesia Nomor 32 Tahun 2004 Tentang Pemerintah Daerah

Undang-Undang Republik Indonesia Nomor 25 Tahun 2007 Tentang Penanaman Modal

Undang-Undang Republik Indonesia Nomor 10 Tahun 2009 Tentang Kepariwisataan

Peraturan Daerah Provinsi Bali Nomor 2 Tahun 2012 tentang Kepariwisataan Budaya Bali

Peraturan Daerah Provinsi Bali Nomor 10 Tahun 2015 Tentang Rencana Induk Pembangunan Kepariwisataan Daerah Provinsi Bali Tahun 2015-2029

\section{Website Resmi}

Badan Pusat Statistik Provinsi Bali, (2020). Perkembangan Pariwisata Provinsi Bali Juli 2020. Retrieved from https://bali.bps.go.id/pressrelease/2020/ 
09/01/717332/perkembangan-pariwisata-provinsi-bali-juli-2020.html diakses 2 September 2020.

Badan Pusat Statistik Provinsi Bali, (2020). Pertumbuhan Ekonomi Bali Semster I - 2020. Retrieved from https://bali.bps.go.id/pressrelease/2020/08/05 /717412/pertumbuhan-ekonomi-bali-semester-i-----2020.html diakses 2 September 2020. 